\title{
Income and Education as the Determinants of Anti-Corruption Attitudes: Evidence from Indonesia
}

\author{
Anita K. Zonebia ${ }^{a, *}$, Arief A. Yusuf ${ }^{a}$, \& Heriyaldi ${ }^{a}$ \\ ${ }^{a}$ Universitas Padjadjaran
}

\begin{abstract}
A higher level of corruption is found to be associated with a lower level of income in most cross-country studies. However, at any given income level, education can also be a very important determinant of the level of corruption, and failing to include education may bias or overestimate the importance of income. We estimated an empirical model of an individual's attitude toward anti-corruption using a large sample of 9,020 individuals who represent the Indonesian population and found that the effect of income (measured by expenditure) is either weakened or eliminated when we controlled for the level of education. The effect of education is also found to exhibit a nonlinear pattern, which implies that investing in education will have increasing returns in the form of an anti-corruption attitude. This finding supports the view that increasing access to education is an effective measure to reduce corruption norms, particularly in developing countries.
\end{abstract}

Keywords: corruption; anti-corruption; development; Indonesia JEL Classification: D73

${ }^{*}$ We would like to thank the Indonesian Statistics Office (BPS) for access to the dataset used in this study. We thank Arya Gaduh, Erlangga Ladiyanto, and others for commenting on the initial findings of the study. Errors are the authors' responsibility. The usual disclaimer applies.

Corresponding Author: CEDS FEB UNPAD, Jalan Hayam Wuruk No. 6-8 Bandung 40115. E-mail: arief.yusuf@unpad.ac.id. 


\section{Introduction}

Studies on the issue of corruption in the context of economic development have been well documented in both theoretical and empirical literature. These studies can be divided into those that focus on the cause of corruption and those that focus on the consequences of corruption. Empirical studies on the causes of corruption have been dominated particularly by cross-country studies (Bardhan, 1997).

Cross-country studies typically ask why governments and bureaucrats are more corrupt in some countries than in others. The Corruption Perceptions Index (CPI), constructed by Transparency International (TI), is used as the most common indicator of a country's level of corruption in finding the determinants of corruption level. Many studies also use other indicators, such as the rating of control of corruption developed by the World Bank and corruption rating published by Political Risk Services (PRS) in its International Country Risk Guide (ICRG). Empirical researchers have tried to empirically model what the best predictors are of the cross-country variations in those indexes.

From the results of those studies, the level of economic development has been consistently found among the strongest determinants of corruption where higher economic development has been associated with a lower level of corruption. Gross domestic product (GDP), the most common proxy of income per capita, has been the common denominator of economic development in those studies. For instance, as reviewed by Treisman (2007), the correlation between GDP per capita and perceived corruption is extremely robust. The relationship survives after controlling for ethnolinguistic, fractionalization, latitude, region, religion, culture, democracy, trade, inequality, inflation, and various policy variables.

Other variables that are considered to be important determinants of corruption in the cross-country empirics are political institutions, including democratization, types of electoral rule, and the degree of freedom of the press. Other than political institutions, rent and market competition are also found to be associated with corruption levels. Natural resource-dependent economies tend to be associated with a higher level of corruption, while more open economies are associated with a lower level of corruption.

This paper is motivated by the fact (among others) that the studies on the causes of corruption, particularly the cross-country studies, have barely considered indicators of the level of development other than income (GDP per capita). In many cases, income per capita is not a good representation of a country's level of development. Education and health, for example, can be considered as important as income per person. The United Nations Development Programme's (UNDP) Human Development Index (HDI) was developed and widely used based on this very argument.

Moreover, the findings of those cross-country studies that particularly suggest that income per capita is among the most important determinants of corruption imply that a country's corruption level will decline when the country's popula- 
tion gets richer. The notion that corruption will vanish eventually as a country develops may overlook its urgency.

Indeed, income per capita is highly correlated with other development indicators, such as education. However, in the context of corruption, it is important to make the distinction between income and education as a predictor of corruption level. The corruption that is motivated by financial needs or even greed will be less common in wealthier societies. The extent of bribery in government bureaucracy, for instance, will be lower when civil servants already have decent salaries but will be very rampant in a country where government employees are paid very low salaries. From this view, income is often hypothesized as a significant factor that affects the level of corruption. When people get richer, corruption will be lower, other things held constant (Ceteris paribus).

Education, however, despite being fairly correlated with income, is important in shaping the corruption norms within a society, at any given level of income. Educated citizens will also demand a cleaner bureaucracy and will have less tolerance toward bribery. In addition, education helps to develop law-abiding societies where corruption is considered a crime. In some countries, corruption can be considered an extraordinary crime. In short, a culture of corruption will be much less accepted in highly educated societies.

The standard approach of using income per capita as a measure of the level of development, yet ignoring education, in predicting the level of corruption can also mislead public policies, particularly in the developing world. If income is so significant in reducing corruption, then extra measures to fight corruption can be considered to be less of a priority in emerging countries where economic growth is high since corruption will decline as the society is becoming wealthier over time.

As pointed out by Treisman (2000: 440), there is strong evidence the process of economic development reduces corruption through the rationalization of public and private roles and the spread of education, among other things. However, when the mechanism works by which income and education affect corruption levels differently and through different channels, both income and education must enter together as predictors of the level of corruption.

Extending education access in many developing countries has also been a development priority. Government budgets have been allocated proportionally to this priority in many countries. Improving access to basic education is one of the most successful achievements of the Millennium Development Goals (MDGs). The poor have also been the main target of universal education. As a result, the progress in achieving universal (basic) education has been progressing quite well in many developing countries and even in less developed societies. Inequality in education outcomes can be significantly lower than inequality in income. As income per capita is a very aggregative measure and more unequally distributed than education (at least basic education), higher income per capita is less indicative toward less corruption rather than higher education outcomes.

Several studies have mentioned this. For example, Treisman (2007: 225), after 
including education attainment in his analysis, did not find evidence that the relationship with development was picking up any effects of greater than average educational attainment.

Other literature that can enlighten the discussion analyzes individual attitudes toward corruption. This type of study uses data from surveys that record individuals' attitudes toward corruption and attempt to model social, economic, and demographic factors can predict their attitudes. Such studies are relatively limited in number compared to cross-country analyses due to the limited availability of this kind of survey. However, some studies do exist (e.g., Gatti et al., 2003; Swamy et al., 2001; Truex, 2011).

Gatti et al. (2003) found that women and individuals who are employed, less wealthy, and older are less accepting of corruption. Focusing on the relationship between gender and corruption, Swamy et al. (2001) found that women are consistently less likely to condone bribery and participate in the discussion.

Truex (2011) used a dataset of 853 individuals surveyed in Nepal and tried to find the determinants of general corruption acceptance for various types of corruption. He found that education consistently emerged as the primary determinant of these attitudes, with more educated respondents showing less accepting attitudes across the range of corrupt behaviors. Furthermore, he found that income (which is a dummy variable of whether or not the respondent is in the category of high income) is not significantly associated with corruption acceptance. He also included other control variables, such as type of occupation, regions, and age.

A study from Nepal by Truex (2011) is the most similar to the study in this paper. First, it used perception or attitude toward corruption as the dependent variable, which is the same dependent variable used in this paper. Second, similar to our paper, it used various dimensions or types of corruption as the dependent variables. In the findings, Truex (2011) also emphasized the importance of education as the variable that he found to be the most robust predictor of corruption acceptance. He called for other researchers to test the strength of these relationships outside of Nepal (Truex, 2011: 39).

Our study offers to improve on Truex's study (2011) in the following ways: First, we use a larger number of individuals in the sample $(9,020$ individuals instead of 853 individuals in Truex's study (2011)). This larger sample offered more degrees of freedom and confidence in the analysis. This sample also represents one country's adult population, offering greater variation. However, the sample in the study by Truex (2011) was collected only in the city of Kathmandu, Nepal. Second, we use a much richer dataset than the analysis from Truex's study (2011) so that we can control for a larger number of relevant variables. For example, in our data, there is information on an individual's access to various types of media. The information and knowledge that one gain from the media can influence his/her attitudes toward corruption. In addition, there is also a variable that measures peer influence. The sector of employment is also another variable that can be important in shaping an individual's attitude toward corruption. All of these 
variables are not included in the control variables in Truex's study (2011). Third, income, which is our focus variable in this paper, is measured rather weakly in Truex's study (2011). It is only a dummy variable, indicating whether or not an individual belongs to the high-income category. In our dataset, the income variable is a categorical variable that consists of six income categories.

In an attempt to enrich the discussion outlined in the literature discussed above, the objective of this paper is to revisit the following question, using the case of Indonesia and paying particular attention to the role of income and education: What are the determinants of anti-corruption norms among individuals?

To answer such a question, we utilized a dataset that is a result of a survey of 10,000 individuals that represent the Indonesian adult population. The survey, which was carried out nationwide in 2011 by the Indonesian Official Statistics Office (BPS), was aimed to elicit the perception of respondents on various kinds of corruption, ranging from bribery to money politics. The survey questions attempted to record to what extent the respondent can accept those kinds of corruption. In addition, the survey also recorded various characteristics of the respondents, including income level, education level, and other sociodemographic characteristics.

We then estimated the model predicting the level of anti-corruption attitudes by using an ordered-probit regression model (as well as Ordinary Least Squares [OLS]). We included income, education, and various other sociodemographic characteristics as control variables. However, we started by excluding education (measured as the schooling years) and including income as the regressors. First, we found that income is associated strongly with anti-corruption attitudes where higher income is correlated with stronger anti-corruption sentiment, which is consistent with previous literature. However, after adding education as another regressor, we found that the effect of income is either weakened or eliminated. The effect of education is also found to exhibit a nonlinear pattern. This implies that investing in education will have increasing returns in the form of anti-corruption attitudes.

The paper is organized as follows: Section 2 discusses the data and econometric model used in the research. Section 3 discusses the findings, and Section 4 presents the research conclusions.

\section{Data and Analytical Method}

\subsection{Data}

The data used in this study were from a survey carried out by the Indonesian Statistics Office (i.e., Badan Pusat Statistik/BPS). The survey, which is called the Anti-Corruption Attitude Survey (i.e., Survey Perilaku Anti Korupsi/SPAK), was given to 9,020 adult individuals in 170 districts in Indonesia. The survey was conducted in 2013 using a multistage sampling method, aimed at representing 
the Indonesian adult population (BPS, 2014). ${ }^{1}$

Each surveyed individual was asked to rate his/her level of acceptance ( 1 =very acceptable, 2 =acceptable, $3=$ less acceptable, and $4=$ unacceptable) toward the following 12 types of corruption:

1. Someone with authority guarantees his/her relative to be accepted in a job application (C1).

2. Someone bribes an individual to process a job application/recruitment (C2).

3. Someone bribes public officials to expedite administration processes (C3).

4. Someone bribes police officers in order to get a driving license (C4).

5. A traffic offender bribes police officers in order to avoid being fined (C5).

6. An official-in-charge for marriage administration asks for some unofficial fees for his/her services (C6).

7. A teacher gets a guarantee for his/her child's enrollment in the school where he/she works (C7).

8. A teacher asks pupils' parents for extra money during his/her pupils' grade promotion (C8).

9. Parents bribe school authorities for their children's enrollment (C9).

10. An employee does other business unrelated to his/her duties during work hours (C10).

11. A politician running for a political position gives money to voters during an election (C11).

12. Voters expect to get money from a politician running for a political position (C12).

Figure 1 and Table 1 show the summary of the respondents' responses to the questions regarding the 12 different types of corruption. Figure 1 shows the average responses (on a scale of 1 to 4 ), where the higher the score, the stronger the level of anti-corruption attitude. On the other hand, Table 1 shows the proportion of respondents who chose each level of anti-corruption attitudes.

As can be seen from the summary, the majority of Indonesian adults (59 percent on average) perceive that corruption, in the form of the 12 mentioned types, is not acceptable. However, the level of the acceptance (or non-acceptance) of corruption varies by the types of corruption. A teacher asking for extra money as part of his/her pupils' grade promotion is seen as the most unacceptable kind of corruption, while bribing public officials to expedite administration processes, such as making identity cards or birth certificates, is the most acceptable type.

In addition to the elicitation of an anti-corruption attitude, the survey also asked for a variety of information from the respondents. This information in-

\footnotetext{
${ }^{1}$ The survey was implemented using a multistage two-phase sampling with the following steps (BPS, 2014): (1) select the districts to be included in the sample with a probability proportional to size (population) (The number of districts selected was 170 districts out of approximately 300.); (2) select census blocks within the selected districts; (3) select 10 households within each of the census blocks; and (4) select (randomly) either the household head or his/her spouse as the respondent.
} 


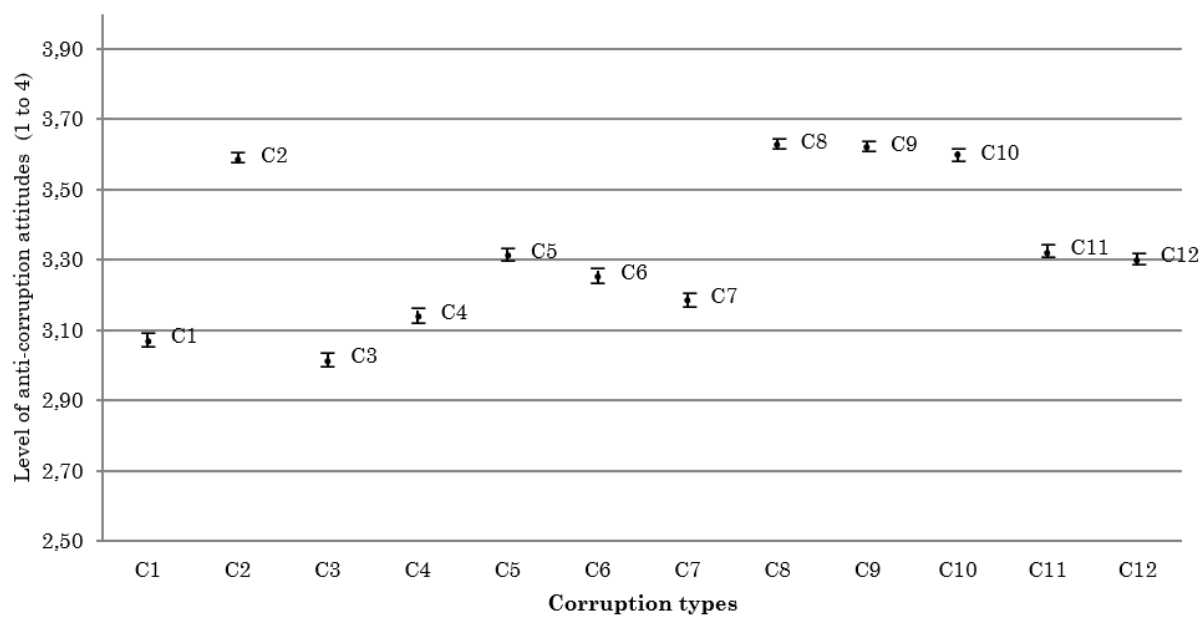

Figure 1: Degrees of Anti-corruption Attitudes (1=very acceptable, 2=acceptable, $3=$ less acceptable, and $4=$ unacceptable)

Table 1: Responses (Degrees of Acceptability) to Various Types of Corruption

\begin{tabular}{|c|c|c|c|c|}
\hline \multirow{3}{*}{ Type of corruption } & \multicolumn{4}{|c|}{ Response (\%) } \\
\hline & (1) Very & $(2)$ & (3) Less & $(4)$ \\
\hline & acceptable & Acceptable & acceptable & Unacceptable \\
\hline Nepotism in work recruitment (C1) & 1.63 & 35.41 & 17.36 & 45.60 \\
\hline Bribery in work recruitment (C2) & 0.49 & 13.13 & 13.55 & 72.84 \\
\hline Illicit giver in government services (C3) & 0.83 & 39.70 & 16.88 & 42.48 \\
\hline Illicit giver in driving license test $(\mathrm{C} 4)$ & 0.76 & 33.14 & 17.64 & 48.46 \\
\hline Bribery in traffic violation (C5) & 0.55 & 24.70 & 17.72 & 57.03 \\
\hline Tips for wedding administration (C6) & 0.61 & 27.23 & 18.65 & 53.51 \\
\hline Nepotism in school enrollment (C7) & 0.99 & 29.56 & 19.49 & 49.97 \\
\hline $\begin{array}{l}\text { Teacher asking for extra money during } \\
\text { pupils' grade promotion }(\mathrm{C} 8)\end{array}$ & 0.28 & 10.53 & 15.53 & 73.66 \\
\hline Bribery in school enrollment (C9) & 0.33 & 10.18 & 16.82 & 72.67 \\
\hline $\begin{array}{l}\text { Moonlighting during normal working } \\
\text { hours (C10) }\end{array}$ & 0.38 & 11.45 & 16.45 & 71.72 \\
\hline $\begin{array}{l}\text { Politician bribing voters during election } \\
\text { (C11) }\end{array}$ & 0.71 & 25.16 & 15.32 & 58.81 \\
\hline $\begin{array}{l}\text { Voters expecting money from politician } \\
\text { (C12) }\end{array}$ & 0.71 & 25.18 & 17.53 & 56.59 \\
\hline Average & 0.69 & 23.78 & 16.91 & 58.61 \\
\hline
\end{tabular}

cluded sociodemographic characteristics, such as age, marital status, and gender, as well as economic variables, including expenditure and status of employment. Relevant to the context of anti-corruption attitude, the survey also asked about the type of media that the respondent accesses that can be used to trace the effect of media influences on anti-corruption behavior. 


\subsection{Analytical Method}

As the dependent variable is a discrete ordered response (with $1=$ very acceptable to $4=$ unacceptable regarding certain types of corruption), we specified the model as an ordered-probit model where:

$$
y^{*}=\mathbf{x}^{\prime} \boldsymbol{\beta}+\varepsilon, \varepsilon \mid \mathbf{x} \sim \operatorname{Normal}(0,1),
$$

where $y *$ is an unobserved latent variable, $\boldsymbol{x}$ is the vector of independent variables, $\beta$ is the parameter to be estimated, and $\varepsilon$ is a standardized normally distributed error term. We observed $y=1,2,3,4$, where $y=1$ when the respondent thinks that the corruption is very acceptable, $y=2$ when the respondent thinks the corruption is acceptable, $y=3$ when the respondent thinks the corruption is less acceptable, and $y=4$ when the respondent thinks the corruption is unacceptable.

In the $\mathbf{x}$, which is the vector of independent variables (regressors), we included expenditure (a proxy of income), some categorical dummy variables dividing a household's monthly expenditure into six classes: years of schooling as a measure of an individual's level of education; an individual's age, gender, marital status, and working status; sectors of employment; types of employment; living areas (rural/urban); access to media; and peer influence, which shows whether or not a respondent has a close friend or relative that is involved in any kind of corruption.

Table 2 shows the summary statistics of the variables used in the estimation.

\section{Result}

\section{Expenditure (proxy of income)}

In almost all of the models (of the 12 corruption behaviors), in general, expenditure is significantly associated with anti-corruption attitudes when we exclude education from the model. The association between income and corruption attitudes, however, is stronger for some types of corruption and somewhat weaker for others. For example, a relatively strong association (i.e., a large coefficient and statistically significant) can be found for corruption types $\mathrm{C} 1, \mathrm{C} 2, \mathrm{C} 8$, and $\mathrm{C} 12$, but a relatively weaker association is found for types $\mathrm{C} 4, \mathrm{C} 5$, and $\mathrm{C} 6$.

However, when we include years of schooling as one of the regressors, almost all of the coefficients of the expenditure categories become smaller and statistically insignificant. The coefficient of expenditure generally remains statistically significant after controlling for education level only in the model of corruption type C12 (bribery related to money politics). However, the magnitude of the coefficients has been largely weakened.

Some cross-country studies, such as Sandholtz and Koetzle (2000), Montinola and Jackman (2002), Paldam (2002), Fisman and Miguel (2006), Gokcekus and Knörich (2006), and Ortega et al. (2010) found that income, measured by GDP per capita, is statistically associated with corruption level. However, these studies 
Table 2: Summary Statistics of Dependent and Independent Variables

\begin{tabular}{|c|c|c|c|c|c|}
\hline & Obs & Mean & $\begin{array}{l}\text { Std. } \\
\text { Dev. }\end{array}$ & Min & Max \\
\hline \multicolumn{6}{|l|}{ Dependent Variables } \\
\hline Nepotism in work recruitment (C1) & 9020 & 3.069 & 0.933 & 1 & 4 \\
\hline Bribery in work recruitment (C2) & 9020 & 3.587 & 0.731 & 1 & 4 \\
\hline Illicit giver in government services (C3) & 9020 & 3.012 & 0.925 & 1 & 4 \\
\hline Illicit giver in driving license test $(\mathrm{C} 4)$ & 9020 & 3.138 & 0.910 & 1 & 4 \\
\hline Bribery in traffic violation (C5) & 9020 & 3.312 & 0.861 & 1 & 4 \\
\hline Tips for wedding administration (C6) & 9020 & 3.251 & 0.877 & 1 & 4 \\
\hline Nepotism in school enrollment (C7) & 9020 & 3.184 & 0.895 & 1 & 4 \\
\hline $\begin{array}{l}\text { Teacher asking for extra money during pupils' grade } \\
\text { promotion }(\mathrm{C} 8)\end{array}$ & 9020 & 3.626 & 0.679 & 1 & 4 \\
\hline Bribery in school enrollment (C9) & 9020 & 3.618 & 0.678 & 1 & 4 \\
\hline Moonlighting during normal working hours (C10) & 9020 & 3.595 & 0.702 & 1 & 4 \\
\hline Politician bribing voters during election (C11) & 9020 & 3.322 & 0.874 & 1 & 4 \\
\hline Voters expecting money from politician (C12) & 9020 & 3.300 & 0.870 & 1 & 4 \\
\hline \multicolumn{6}{|l|}{ Independent Variables } \\
\hline Age $<30$ (Reference group) & 9020 & 0.089 & 0.285 & 0 & 1 \\
\hline Age $30-49$ & 9020 & 0.519 & 0.500 & 0 & 1 \\
\hline Age $50-64$ & 9020 & 0.288 & 0.453 & 0 & 1 \\
\hline Age $65+$ & 9020 & 0.104 & 0.305 & 0 & 1 \\
\hline Male & 9020 & 0.434 & 0.496 & 0 & 1 \\
\hline Years of schooling & 9020 & 7.240 & 5.307 & 0 & 22 \\
\hline Years of schooling square & 9020 & 80.577 & 85.124 & 0 & 484 \\
\hline Single (Reference group) & 9020 & 0.029 & 0.167 & 0 & 1 \\
\hline Married/divorced & 9020 & 0.971 & 0.167 & 0 & 1 \\
\hline Working & 9020 & 0.706 & 0.456 & 0 & 1 \\
\hline Primary sector (Reference group) & 9020 & 0.224 & 0.417 & 0 & 1 \\
\hline Secondary sector & 9020 & 0.126 & 0.332 & 0 & 1 \\
\hline Tertiary sector & 9020 & 0.345 & 0.475 & 0 & 1 \\
\hline Casual worker (Reference group) & 9020 & 0.146 & 0.353 & 0 & 1 \\
\hline Entrepreneur & 9020 & 0.356 & 0.479 & 0 & 1 \\
\hline Employee & 9020 & 0.160 & 0.366 & 0 & 1 \\
\hline Civil servant & 9020 & 0.040 & 0.197 & 0 & 1 \\
\hline Expenditure $\mathrm{Rp}<1$ million (Reference group) & 9020 & 0.250 & 0.433 & 0 & 1 \\
\hline Expenditure Rp 1-2.9 million & 9020 & 0.570 & 0.495 & 0 & 1 \\
\hline Expenditure Rp 3-5.9 million & 9020 & 0.156 & 0.363 & 0 & 1 \\
\hline Expenditure Rp 6-9.9 million & 9020 & 0.018 & 0.134 & 0 & 1 \\
\hline Expenditure Rp 10-14.9 million & 9020 & 0.003 & 0.059 & 0 & 1 \\
\hline Expenditure $\mathrm{Rp} \geq 15$ million & 9020 & 0.002 & 0.041 & 0 & 1 \\
\hline Log (expenditure) & 9020 & 14.307 & 0.771 & 13.122 & 16.524 \\
\hline Urban & 9020 & 0.696 & 0.460 & 0 & 1 \\
\hline Mass media access & 9020 & 2.594 & 0.925 & 1 & 4 \\
\hline Peer influence & 9020 & 0.085 & 0.278 & 0 & 1 \\
\hline
\end{tabular}

excluded education in the regressors. Truex (2011), has found similar findings using data from Kathmandu, Nepal. Education is highly associated with an individual's anti-corruption attitude, while income is not as highly associated with this attitude.

As shown in the results, the weak association of income and level of anticorruption attitude after controlling for education may suggest that the income- 
corruption relationship is not as strong as what many other studies have suggested. The strong association may have been picking up the effect of education on the level of corruption.

\section{Education (years of schooling)}

In general, the results suggest that education is associated significantly with the level of anti-corruption attitude. Education is measured by using the years of schooling and entered in the equation nonlinearly by adding its square. By adding its square, we attempted to test if the effect of education is increasing or decreasing with the level of education.

In 11 out of the 12 regressions, years of schooling is statistically significant, confirming the close association between education and attitude toward anticorruption. Having a higher education level is associated with a higher tendency to regard corruption (of all types) as unacceptable. The coefficient size of years of schooling does not vary much across different types of corruption. The relatively strongest association is found in corruption type C8 (i.e., teacher asking for extra money during his/her pupils' grade promotion), yet in general, not so much different. The result of this study confirms the finding of Truex (2011), which is a robust relationship between education and anti-corruption attitude using survey data from Kathmandu, Nepal.

In 7 of the 12 model specifications (of various types of corruption), we found that the square of years of schooling is positive and statistically significant. This suggests a convex relationship between years of schooling and attitude toward anti-corruption. This means that the marginal effect of an increase in the number of years of schooling is nonlinear, higher in the domain of a high education level and lower in the domain of a low education level. This convex relationship suggests that the return to education (in the form of anti-corruption attitude) is becoming higher when the base level of education is higher. In this case, investment in access to education will have an increasing return to scale. This emphasizes the importance of education in shaping the anti-corruption norms among individuals within the Indonesian society.

This is consistent with previous findings in the literature. Education has been believed to be the driver of moral perspective and people's attitudes (Hauk \& Saez-Marti, 2002). Many studies have confirmed the education-anticorruption association, such as Truex (2011), Chatterjee and Ray (2012), Guerrero and Rodríguez-Oreggia (2008), Olken (2009), Alfonso (2013), and Melgar et al. (2010).

\section{Other variables}

Age does not seem to be associated with anti-corruption attitude. The coefficients are not statistically significant in most of the regressions. On the other hand, the effect of gender is mixed. The tendency, however, is that males tend to have a stronger anti-corruption attitude than females, as almost half of the regressions 
Table 3: Results of the ordered-probit regression model

\begin{tabular}{|c|c|c|c|c|c|c|}
\hline \multirow{2}{*}{ Variable } & \multicolumn{2}{|c|}{ C1 } & \multicolumn{2}{|c|}{ C2 } & \multicolumn{2}{|c|}{ C3 } \\
\hline & [1] & {$[2]$} & [1] & {$[2]$} & {$[1]$} & [2] \\
\hline \multirow[t]{2}{*}{ Expenditure Rp 1-2.9 million } & $0.086^{* * *}$ & 0.047 & $0.072^{* *}$ & 0.042 & 0.026 & -0.015 \\
\hline & -0.03 & -0.031 & -0.034 & -0.034 & -0.031 & -0.031 \\
\hline \multirow[t]{2}{*}{ Expenditure Rp 3-5.9 million } & $0.161^{* * *}$ & 0.013 & $0.130^{* * *}$ & 0.014 & $0.112^{* *}$ & -0.035 \\
\hline & -0.044 & -0.045 & -0.05 & -0.052 & -0.044 & -0.046 \\
\hline \multirow[t]{2}{*}{ Expenditure Rp 6-9.9 million } & $0.172^{*}$ & -0.053 & $0.289^{* *}$ & 0.114 & $0.216^{* *}$ & -0.004 \\
\hline & -0.098 & -0.101 & -0.13 & -0.133 & -0.097 & -0.101 \\
\hline \multirow{2}{*}{$\begin{array}{l}\text { Expenditure Rp 10-14.9 mil- } \\
\text { lion }\end{array}$} & $0.512^{* *}$ & 0.187 & 0.034 & -0.265 & $0.402^{*}$ & 0.083 \\
\hline & -0.228 & -0.223 & -0.258 & -0.264 & -0.219 & -0.218 \\
\hline \multirow[t]{3}{*}{ Expenditure $\mathrm{Rp} \geq 15$ million } & 0.429 & 0.229 & 0.109 & -0.046 & 0.437 & 0.256 \\
\hline & -0.268 & -0.257 & -0.363 & -0.35 & -0.344 & -0.319 \\
\hline & & $0.017^{* *}$ & & 0.01 & & $0.018^{* * *}$ \\
\hline \multirow[t]{2}{*}{ Years of schooling } & & -0.007 & & -0.008 & & -0.007 \\
\hline & & $0.002^{* * *}$ & & $0.002^{* * *}$ & & $0.001^{* * *}$ \\
\hline \multirow[t]{2}{*}{ Years of schooling square } & & 0.000 & & -0.001 & & 0.000 \\
\hline & 0.006 & 0.041 & $-0.132^{* *}$ & $-0.104^{*}$ & $-0.088^{*}$ & -0.054 \\
\hline \multirow[t]{2}{*}{ Age $30-49$} & -0.046 & -0.046 & -0.054 & -0.054 & -0.045 & -0.045 \\
\hline & -0.044 & 0.058 & $-0.136^{* *}$ & -0.054 & $-0.116^{* *}$ & -0.016 \\
\hline \multirow[t]{2}{*}{ Age 50-64 } & -0.049 & -0.051 & -0.057 & -0.058 & -0.049 & -0.05 \\
\hline & 0.022 & $0.141^{* *}$ & -0.06 & 0.005 & -0.061 & 0.056 \\
\hline \multirow[t]{2}{*}{ Age 65+ } & -0.058 & -0.06 & -0.066 & -0.068 & -0.058 & -0.06 \\
\hline & $0.068^{* *}$ & $0.049^{*}$ & 0.041 & 0.026 & $0.067^{* *}$ & $0.047^{*}$ \\
\hline \multirow[t]{2}{*}{ Male } & -0.027 & -0.027 & -0.031 & -0.031 & -0.027 & -0.027 \\
\hline & $-0.163^{* *}$ & -0.096 & -0.088 & -0.033 & $-0.174^{* *}$ & -0.111 \\
\hline \multirow[t]{2}{*}{ Married/divorce } & -0.079 & -0.08 & -0.089 & -0.09 & -0.075 & -0.076 \\
\hline & -0.067 & -0.012 & -0.059 & -0.018 & -0.05 & 0.006 \\
\hline \multirow[t]{2}{*}{ Working } & -0.044 & -0.045 & -0.049 & -0.049 & -0.045 & -0.046 \\
\hline & -0.029 & -0.024 & 0.017 & 0.021 & -0.02 & -0.017 \\
\hline \multirow[t]{2}{*}{ Secondary sector } & -0.046 & -0.046 & -0.052 & -0.052 & -0.047 & -0.047 \\
\hline & $0.101^{* * *}$ & 0.062 & 0.057 & 0.027 & $0.109^{* * *}$ & $0.070^{*}$ \\
\hline \multirow[t]{2}{*}{ Tertiary sector } & -0.038 & -0.038 & -0.043 & -0.043 & -0.038 & -0.038 \\
\hline & -0.03 & -0.034 & -0.036 & -0.039 & -0.03 & -0.035 \\
\hline \multirow[t]{2}{*}{ Entrepreneur } & -0.04 & -0.04 & -0.044 & -0.044 & -0.04 & -0.04 \\
\hline & $0.082^{*}$ & -0.017 & $0.089^{*}$ & 0.009 & $0.119^{* *}$ & 0.021 \\
\hline \multirow[t]{2}{*}{ Employee } & -0.048 & -0.049 & -0.054 & -0.054 & -0.048 & -0.049 \\
\hline & $0.424^{* * *}$ & 0.132 & $0.325^{* * *}$ & 0.064 & $0.224^{* * *}$ & -0.059 \\
\hline \multirow[t]{2}{*}{ Civil servant } & -0.079 & -0.083 & -0.093 & -0.099 & -0.076 & -0.082 \\
\hline & $0.098^{* * *}$ & $0.053^{*}$ & $0.222^{* * *}$ & $0.188^{* * *}$ & $0.082^{* * *}$ & 0.037 \\
\hline Urban & -0.029 & -0.03 & -0.033 & -0.033 & -0.03 & -0.03 \\
\hline & $0.173^{* * *}$ & $0.126^{* * *}$ & $0.172^{* * *}$ & $0.134^{* * *}$ & $0.153^{* * *}$ & $0.106^{* * *}$ \\
\hline Mass media access & -0.015 & -0.016 & -0.017 & -0.018 & -0.015 & -0.016 \\
\hline & 0.007 & -0.012 & $-0.184^{* * *}$ & $-0.201^{* * *}$ & -0.057 & $-0.077^{*}$ \\
\hline Peer influence & -0.046 & -0.046 & -0.05 & -0.05 & -0.045 & -0.045 \\
\hline r2_p & 0.024 & 0.032 & 0.027 & 0.033 & 0.018 & 0.026 \\
\hline $\mathrm{N}^{-1}$ & 9020 & 9020 & 9020 & 9020 & 9020 & 9020 \\
\hline chi2 & 470.774 & 613.718 & 379.722 & 438.542 & 348.479 & 506.33 \\
\hline
\end{tabular}

Note: Robust standard errors are in parentheses. ${ }^{*} \mathrm{p}<0.1,{ }^{* *} \mathrm{p}<0.05,{ }^{* * *} \mathrm{p}<0.01$ 
Table 3: Results of the ordered-probit regression model (continued)

\begin{tabular}{|c|c|c|c|c|c|c|}
\hline \multirow{2}{*}{ Variable } & \multicolumn{2}{|c|}{$\mathrm{C} 4$} & \multicolumn{2}{|c|}{ C5 } & \multicolumn{2}{|c|}{ C6 } \\
\hline & [1] & [2] & [1] & {$[2]$} & [1] & {$[2]$} \\
\hline \multirow[t]{2}{*}{ Expenditure Rp 1-2.9 million } & -0.024 & $-0.065^{* *}$ & 0.013 & -0.027 & 0.043 & 0.024 \\
\hline & -0.031 & -0.031 & -0.031 & -0.032 & -0.031 & -0.031 \\
\hline \multirow[t]{2}{*}{ Expenditure Rp 3-5.9 million } & $0.112^{* *}$ & -0.033 & $0.113^{* *}$ & -0.025 & 0.023 & -0.034 \\
\hline & -0.044 & -0.046 & -0.046 & -0.047 & -0.044 & -0.046 \\
\hline \multirow[t]{2}{*}{ Expenditure Rp 6-9.9 million } & $0.198^{* *}$ & -0.012 & 0.159 & -0.039 & 0.011 & -0.051 \\
\hline & -0.101 & -0.103 & -0.101 & -0.103 & -0.099 & -0.101 \\
\hline \multirow{2}{*}{$\begin{array}{l}\text { Expenditure Rp 10-14.9 mil- } \\
\text { lion }\end{array}$} & 0.244 & -0.058 & 0.32 & 0.045 & 0.243 & 0.169 \\
\hline & -0.269 & -0.268 & -0.242 & -0.237 & -0.23 & -0.232 \\
\hline \multirow[t]{3}{*}{ Expenditure $R p \geq 15$ million } & 0.352 & 0.166 & $0.742^{*}$ & 0.603 & 0.039 & -0.014 \\
\hline & -0.375 & -0.355 & -0.408 & -0.39 & -0.277 & -0.279 \\
\hline & & $0.023^{* * *}$ & & $0.024^{* * *}$ & & $0.026^{* * *}$ \\
\hline \multirow[t]{2}{*}{ Years of schooling } & & -0.007 & & -0.007 & & -0.007 \\
\hline & & $0.001^{* *}$ & & $0.001^{* *}$ & & -0.01 \\
\hline \multirow[t]{2}{*}{ Years of schooling square } & & 0.000 & & 0.000 & & -0.007 \\
\hline & -0.047 & -0.012 & -0.033 & 0.003 & 0.052 & 0.071 \\
\hline \multirow[t]{2}{*}{ Age 30-49 } & -0.045 & -0.045 & -0.047 & -0.047 & -0.045 & -0.045 \\
\hline & -0.038 & 0.068 & 0.016 & $0.123^{* *}$ & 0.031 & $0.088^{*}$ \\
\hline \multirow[t]{2}{*}{ Age 50-64 } & -0.048 & -0.05 & -0.05 & -0.051 & -0.049 & -0.05 \\
\hline & -0.005 & $0.121^{* *}$ & 0.016 & $0.146^{* *}$ & 0.029 & $0.106^{*}$ \\
\hline \multirow[t]{2}{*}{ Age $65+$} & -0.058 & -0.06 & -0.06 & -0.062 & -0.058 & -0.06 \\
\hline & $0.059^{* *}$ & 0.039 & $0.086^{* * *}$ & $0.066^{* *}$ & 0.032 & 0.021 \\
\hline \multirow[t]{2}{*}{ Male } & -0.027 & -0.027 & -0.028 & -0.028 & -0.027 & -0.028 \\
\hline & $-0.219^{* * *}$ & $-0.158^{* *}$ & -0.114 & -0.052 & -0.02 & -0.004 \\
\hline \multirow[t]{2}{*}{ Married/divorce } & -0.077 & -0.078 & -0.084 & -0.085 & -0.079 & -0.079 \\
\hline & $-0.112^{* *}$ & -0.055 & $-0.108^{* *}$ & -0.051 & -0.032 & -0.002 \\
\hline \multirow[t]{2}{*}{ Working } & -0.045 & -0.046 & -0.045 & -0.045 & -0.045 & -0.045 \\
\hline & 0.037 & 0.039 & 0.003 & 0.004 & 0.02 & 0.012 \\
\hline \multirow[t]{2}{*}{ Secondary sector } & -0.048 & -0.048 & -0.047 & -0.047 & -0.047 & -0.048 \\
\hline & $0.106^{* * *}$ & $0.067^{*}$ & $0.076^{*}$ & 0.036 & $0.064^{*}$ & 0.045 \\
\hline \multirow[t]{2}{*}{ Tertiary sector } & -0.039 & -0.039 & -0.039 & -0.039 & -0.039 & -0.039 \\
\hline & 0.034 & 0.029 & -0.011 & -0.015 & 0.011 & 0.008 \\
\hline \multirow[t]{2}{*}{ Entrepreneur } & -0.04 & -0.04 & -0.04 & -0.04 & -0.04 & -0.04 \\
\hline & $0.130^{* * *}$ & 0.031 & $0.183^{* * *}$ & $0.090^{*}$ & 0.074 & 0.041 \\
\hline \multirow[t]{2}{*}{ Employee } & -0.049 & -0.05 & -0.049 & -0.05 & -0.048 & -0.049 \\
\hline & $0.306^{* * *}$ & 0.025 & $0.356^{* * *}$ & 0.083 & $0.215^{* * *}$ & $0.146^{*}$ \\
\hline \multirow[t]{2}{*}{ Civil servant } & -0.077 & -0.082 & -0.081 & -0.086 & -0.08 & -0.085 \\
\hline & $0.181^{* * *}$ & $0.137^{* * *}$ & $0.304^{* * *}$ & $0.261^{* * *}$ & 0.005 & -0.016 \\
\hline Urban & -0.03 & -0.03 & -0.03 & -0.03 & -0.03 & -0.03 \\
\hline & $0.164^{* * *}$ & $0.115^{* * *}$ & $0.155^{* * *}$ & $0.108^{* * *}$ & $0.093^{* * *}$ & $0.069^{* * *}$ \\
\hline Mass media access & -0.015 & -0.016 & -0.016 & -0.016 & -0.015 & -0.016 \\
\hline & $-0.110^{* *}$ & $-0.128^{* * *}$ & -0.055 & -0.072 & $-0.093^{* *}$ & $-0.094^{* *}$ \\
\hline Peer influence & -0.045 & -0.045 & -0.047 & -0.047 & -0.045 & -0.045 \\
\hline r2_p & 0.023 & 0.031 & 0.031 & 0.039 & 0.006 & 0.007 \\
\hline $\mathrm{N}^{-1}$ & 9020 & 9020 & 9020 & 9020 & 9020 & 9020 \\
\hline chi2 & 443.296 & 582.392 & 564.52 & 684.372 & 103.422 & 134.214 \\
\hline
\end{tabular}

Note: Robust standard errors are in parentheses. ${ }^{*} \mathrm{p}<0.1,{ }^{* *} \mathrm{p}<0.05,{ }^{* * *} \mathrm{p}<0.01$ 
Table 3: Results of the ordered-probit regression model (continued)

\begin{tabular}{|c|c|c|c|c|c|c|}
\hline \multirow{2}{*}{ Variable } & \multicolumn{2}{|c|}{ C7 } & \multicolumn{2}{|c|}{ C8 } & \multicolumn{2}{|c|}{ C9 } \\
\hline & [1] & {$[2]$} & {$[1]$} & [2] & [1] & [2] \\
\hline \multirow[t]{2}{*}{ Expenditure Rp 1-2.9 million } & $0.053^{*}$ & 0.037 & $0.133^{* * *}$ & $0.096^{* * *}$ & $0.131^{* * *}$ & $0.101^{* * *}$ \\
\hline & -0.03 & -0.031 & -0.034 & -0.034 & -0.034 & -0.034 \\
\hline \multirow[t]{2}{*}{ Expenditure Rp 3-5.9 million } & 0.031 & -0.014 & $0.204^{* * *}$ & 0.074 & $0.187^{* * *}$ & $0.088^{*}$ \\
\hline & -0.044 & -0.045 & -0.05 & -0.052 & -0.049 & -0.051 \\
\hline \multirow[t]{2}{*}{ Expenditure Rp 6-9.9 million } & 0.033 & -0.015 & $0.258^{* *}$ & 0.084 & 0.163 & 0.03 \\
\hline & -0.107 & -0.11 & -0.125 & -0.129 & -0.112 & -0.115 \\
\hline \multirow{2}{*}{$\begin{array}{l}\text { Expenditure Rp 10-14.9 mil- } \\
\text { lion }\end{array}$} & 0.186 & 0.126 & 0.409 & 0.156 & -0.096 & -0.291 \\
\hline & -0.204 & -0.207 & -0.281 & -0.287 & -0.238 & -0.237 \\
\hline \multirow[t]{3}{*}{ Expenditure $R p \geq 15$ million } & 0.089 & 0.043 & 0.541 & 0.389 & 0.203 & 0.088 \\
\hline & -0.319 & -0.321 & -0.36 & -0.363 & -0.344 & -0.332 \\
\hline & & $0.022^{* * *}$ & & $0.033^{* * *}$ & & $0.025^{* * *}$ \\
\hline \multirow[t]{2}{*}{ Years of schooling } & & -0.007 & & -0.008 & & -0.008 \\
\hline & & -0.001 & & 0.000 & & 0.000 \\
\hline \multirow[t]{2}{*}{ Years of schooling square } & & 0.000 & & -0.001 & & -0.001 \\
\hline & -0.014 & 0.002 & 0.036 & 0.076 & $-0.086^{*}$ & -0.055 \\
\hline \multirow[t]{2}{*}{ Age 30-49 } & -0.045 & -0.045 & -0.052 & -0.052 & -0.052 & -0.052 \\
\hline & -0.034 & 0.014 & 0.052 & $0.168^{* * *}$ & $-0.156^{* * *}$ & -0.069 \\
\hline \multirow[t]{2}{*}{ Age 50-64 } & -0.048 & -0.049 & -0.055 & -0.056 & -0.055 & -0.057 \\
\hline & $-0.113^{* *}$ & -0.05 & 0.09 & $0.236^{* * *}$ & $-0.203^{* * *}$ & -0.096 \\
\hline \multirow[t]{2}{*}{ Age $65+$} & -0.057 & -0.059 & -0.065 & -0.067 & -0.064 & -0.067 \\
\hline & 0.037 & 0.028 & 0.03 & 0.011 & 0.038 & 0.023 \\
\hline \multirow[t]{2}{*}{ Male } & -0.027 & -0.027 & -0.031 & -0.031 & -0.031 & -0.031 \\
\hline & 0.021 & 0.032 & $-0.231^{* *}$ & $-0.182^{*}$ & -0.039 & -0.005 \\
\hline \multirow[t]{2}{*}{ Married/divorce } & -0.078 & -0.078 & -0.092 & -0.093 & -0.086 & -0.087 \\
\hline & -0.017 & 0.007 & -0.058 & -0.002 & -0.055 & -0.013 \\
\hline \multirow[t]{2}{*}{ Working } & -0.044 & -0.044 & -0.049 & -0.049 & -0.05 & -0.05 \\
\hline & 0.068 & 0.062 & 0.008 & 0.004 & $0.094^{*}$ & $0.089 *$ \\
\hline \multirow[t]{2}{*}{ Secondary sector } & -0.046 & -0.046 & -0.052 & -0.053 & -0.053 & -0.053 \\
\hline & $0.100^{* * *}$ & $0.084^{* *}$ & $0.104^{* *}$ & 0.066 & $0.123^{* * *}$ & $0.092^{* *}$ \\
\hline \multirow[t]{2}{*}{ Tertiary sector } & -0.038 & -0.038 & -0.043 & -0.043 & -0.043 & -0.043 \\
\hline & -0.024 & -0.027 & 0.031 & 0.026 & -0.029 & -0.032 \\
\hline \multirow[t]{2}{*}{ Entrepreneur } & -0.04 & -0.04 & -0.044 & -0.044 & -0.044 & -0.044 \\
\hline & -0.054 & $-0.081^{*}$ & 0.081 & -0.002 & 0.024 & -0.039 \\
\hline \multirow[t]{2}{*}{ Employee } & -0.048 & -0.049 & -0.055 & -0.055 & -0.054 & -0.055 \\
\hline & 0.067 & 0.014 & $0.453^{* * *}$ & $0.220^{* *}$ & $0.231^{* *}$ & 0.053 \\
\hline \multirow[t]{2}{*}{ Civil servant } & -0.08 & -0.084 & -0.099 & -0.103 & -0.092 & -0.097 \\
\hline & -0.035 & $-0.051^{*}$ & $0.142^{* * *}$ & $0.098^{* * *}$ & $0.176^{* * *}$ & $0.144^{* * *}$ \\
\hline Urban & -0.029 & -0.03 & -0.033 & -0.034 & -0.033 & -0.033 \\
\hline & $0.114^{* * *}$ & $0.095^{* * *}$ & $0.124^{* * *}$ & $0.076^{* * *}$ & $0.146^{* * *}$ & $0.109^{* * *}$ \\
\hline Mass media access & -0.015 & -0.015 & -0.017 & -0.017 & -0.017 & -0.017 \\
\hline & $0.092^{* *}$ & $0.090^{* *}$ & -0.036 & -0.049 & $-0.147^{* * *}$ & $-0.157^{* * *}$ \\
\hline Peer influence & -0.044 & -0.044 & -0.051 & -0.051 & -0.05 & -0.05 \\
\hline $\mathrm{r} 2 \mathrm{p}$ & 0.007 & 0.009 & 0.022 & 0.03 & 0.026 & 0.03 \\
\hline $\mathrm{N}^{1}$ & 9020 & 9020 & 9020 & 9020 & 9020 & 9020 \\
\hline chi2 & 138.311 & 162.209 & 295.835 & 399.581 & 363.526 & 426.892 \\
\hline
\end{tabular}

Note: Robust standard errors are in parentheses. ${ }^{*} \mathrm{p}<0.1,{ }^{* *} \mathrm{p}<0.05,{ }^{* * *} \mathrm{p}<0.01$ 
Table 3: Results of the ordered-probit regression model (continued)

\begin{tabular}{|c|c|c|c|c|c|c|}
\hline \multirow{2}{*}{ Variable } & \multicolumn{2}{|c|}{ C10 } & \multicolumn{2}{|c|}{ C11 } & \multicolumn{2}{|c|}{ C12 } \\
\hline & [1] & [2] & [1] & {$[2]$} & [1] & [2] \\
\hline \multirow[t]{2}{*}{ Expenditure Rp 1-2.9 million } & $0.135^{* * *}$ & $0.108^{* * *}$ & $0.074^{* *}$ & 0.034 & $0.157^{* * *}$ & $0.121^{* * *}$ \\
\hline & -0.034 & -0.034 & -0.032 & -0.032 & -0.032 & -0.032 \\
\hline \multirow[t]{2}{*}{ Expenditure Rp 3-5.9 million } & $0.094^{*}$ & 0.013 & $0.294^{* * *}$ & $0.138^{* * *}$ & $0.341^{* * *}$ & $0.204^{* * *}$ \\
\hline & -0.049 & -0.051 & -0.047 & -0.049 & -0.046 & -0.048 \\
\hline \multirow[t]{2}{*}{ Expenditure Rp 6-9.9 million } & $0.263^{* *}$ & 0.163 & $0.293^{* * *}$ & 0.056 & $0.612^{* * *}$ & $0.408^{* * *}$ \\
\hline & -0.11 & -0.113 & -0.104 & -0.108 & -0.104 & -0.107 \\
\hline \multirow{2}{*}{$\begin{array}{l}\text { Expenditure Rp 10-14.9 mil- } \\
\text { lion }\end{array}$} & 0.096 & -0.043 & $0.643^{* *}$ & 0.341 & $0.518^{* *}$ & 0.237 \\
\hline & -0.249 & -0.252 & -0.266 & -0.246 & -0.232 & -0.224 \\
\hline \multirow[t]{3}{*}{ Expenditure $\geq 15$ millionRp } & 0.379 & 0.287 & $0.772^{*}$ & 0.568 & $1.521^{* * *}$ & $1.406^{* * *}$ \\
\hline & -0.317 & -0.32 & -0.427 & -0.429 & -0.454 & -0.427 \\
\hline & & $0.032^{* * *}$ & & $0.014^{*}$ & & $0.014^{* *}$ \\
\hline \multirow[t]{2}{*}{ Years of schooling } & & -0.008 & & -0.008 & & -0.007 \\
\hline & & -0.001 & & $0.002^{* * *}$ & & $0.002^{* * *}$ \\
\hline \multirow[t]{2}{*}{ Years of schooling square } & & -0.001 & & 0.000 & & 0.000 \\
\hline & 0.008 & 0.037 & -0.061 & -0.022 & -0.047 & -0.014 \\
\hline \multirow[t]{2}{*}{ Age $30-49$} & -0.051 & -0.051 & -0.047 & -0.048 & -0.047 & -0.047 \\
\hline & -0.036 & 0.045 & -0.064 & 0.046 & -0.009 & $0.086^{*}$ \\
\hline \multirow[t]{2}{*}{ Age 50-64 } & -0.054 & -0.056 & -0.050 & -0.052 & -0.050 & -0.051 \\
\hline & -0.089 & 0.017 & $-0.132^{* *}$ & -0.008 & $-0.124^{* *}$ & -0.013 \\
\hline \multirow[t]{2}{*}{ Age 65+ } & -0.064 & -0.066 & -0.059 & -0.062 & -0.059 & -0.062 \\
\hline & 0.030 & 0.015 & $0.095^{* * *}$ & $0.074^{* * *}$ & 0.028 & 0.008 \\
\hline \multirow[t]{2}{*}{ Male } & -0.030 & -0.030 & -0.028 & -0.028 & -0.028 & -0.028 \\
\hline & -0.016 & 0.005 & -0.078 & -0.01 & -0.104 & -0.046 \\
\hline \multirow[t]{2}{*}{ Married/divorce } & -0.080 & -0.080 & -0.078 & -0.079 & -0.077 & -0.077 \\
\hline & -0.074 & -0.034 & $-0.100^{* *}$ & -0.043 & -0.057 & -0.006 \\
\hline \multirow[t]{2}{*}{ Working } & -0.048 & -0.049 & -0.046 & -0.046 & -0.046 & -0.046 \\
\hline & 0.003 & -0.003 & $-0.131^{* * *}$ & $-0.125^{* * *}$ & $-0.121^{* * *}$ & $-0.117^{* *}$ \\
\hline \multirow[t]{2}{*}{ Secondary sector } & -0.051 & -0.051 & -0.048 & -0.048 & -0.047 & -0.047 \\
\hline & $0.086^{* *}$ & 0.061 & 0.008 & -0.035 & $-0.078^{* *}$ & $-0.117^{* * *}$ \\
\hline \multirow[t]{2}{*}{ Tertiary sector } & -0.042 & -0.042 & -0.040 & -0.040 & -0.040 & -0.04 \\
\hline & 0.055 & 0.052 & 0.059 & 0.055 & $0.097^{* *}$ & $0.095^{* *}$ \\
\hline \multirow[t]{2}{*}{ Entrepreneur } & -0.043 & -0.043 & -0.041 & -0.041 & -0.041 & -0.041 \\
\hline & 0.064 & 0.013 & $0.143^{* * *}$ & 0.037 & $0.171^{* * *}$ & 0.079 \\
\hline \multirow[t]{2}{*}{ Employee } & -0.053 & -0.054 & -0.050 & -0.051 & -0.049 & -0.05 \\
\hline & 0.139 & 0.018 & $0.563^{* * *}$ & $0.243^{* * *}$ & $0.474^{* * *}$ & $0.196^{* *}$ \\
\hline \multirow[t]{2}{*}{ Civil servant } & -0.085 & -0.090 & -0.088 & -0.093 & -0.084 & -0.089 \\
\hline & -0.045 & $-0.075^{* *}$ & -0.001 & -0.047 & -0.031 & $-0.073^{* *}$ \\
\hline Urban & -0.033 & -0.033 & -0.031 & -0.032 & -0.031 & -0.031 \\
\hline & $0.155^{* * *}$ & -0.03 & $0.192^{* * *}$ & $0.143^{* * *}$ & $0.132^{* * *}$ & $0.088^{* * *}$ \\
\hline Mass media access & -0.017 & -0.017 & -0.016 & -0.016 & -0.015 & -0.016 \\
\hline & $-0.200^{* * *}$ & $-0.206^{* * *}$ & $-0.140^{* * *}$ & $-0.162^{* * *}$ & $-0.175^{* * *}$ & $-0.194^{* * *}$ \\
\hline Peer influence & -0.050 & -0.050 & -0.047 & -0.047 & -0.046 & -0.046 \\
\hline $\mathrm{r} 2 \mathrm{p}$ & 0.015 & 0.018 & 0.028 & 0.037 & 0.019 & 0.026 \\
\hline $\mathrm{N}^{1}$ & 9020 & 9020 & 9020 & 9020 & 9020 & 9020 \\
\hline chi2 & 205.762 & 259.222 & 471.074 & 630.754 & 342.788 & 474.533 \\
\hline
\end{tabular}

Note: Robust standard errors are in parentheses. ${ }^{*} \mathrm{p}<0.1,{ }^{* *} \mathrm{p}<0.05,{ }^{* * *} \mathrm{p}<0.01$ 
where gender is significant suggest that relationship. This is in contrast with the studies by Swamy et al. (2001) and Dollar et al. (2001) who found that women are consistently less likely to condone bribery. However, other studies, such as Esarey and Chirillo (2013) and Alatas et al. (2006), found that gender is not associated with anti-corruption attitude. They argued that in developed countries where there is better law enforcement, women tend to be more risk-averse in committing crimes like corruption. However, in developing countries where law enforcement is low and corruption is more the norm, that risk aversion becomes less relevant, and women can have a weaker anti-corruption attitude than men (Esarey \& Chirillo, 2013).

The effects of marital status and employment status are also mixed. In general, however, there is no indication of a strong or robust relationship between these two variables and attitude toward anti-corruption. In addition, mixed results are found for sector and type of employment.

In general, mixed results are also found for the association between being located in urban areas and level of anti-corruption attitude. Melgar et al. (2010), in general, found similar results. However, for those with a statistically significant association, being located in urban areas is significantly associated with stronger anti-corruption sentiments. A strong association is found for corruption types C2 (bribery in work recruitment) and C5 (bribery in traffic violation). This tendency may support the hypothesis put forward by Donald R. Cressey $(1950,1953)$ suggesting that cheating, crime or even corruption occurs whenever there is an opportunity. This can explain why individuals in urban areas, when compared to those living in rural areas, tend to care and be concerned more about specific types of corruption, as they are more educated by what often happens around them.

Another variable that is a strong determinant of anti-corruption attitude is an individual's access to different types of media (i.e., television, radio, and newspaper). Access to media is statistically significant in most of the models predicting different types of corruptions. In the survey, respondents were asked whether they received information from such media on the issue of corruption. The results suggest that individuals who claimed to have received such information are more likely to have a stronger anti-corruption attitude than those who did not receive such information. Many previous studies found similar conclusions. Francken et al. (2005), for example, found that that corruption can be constrained successfully through a combination of media programs and monitoring.

In the survey, respondents were also questioned whether or not they remembered any relatives or friends who committed corruption. To some extent, we can use this as a proxy for the peer effect or environment effect, as people who are relatively closer with the culture of corruption may tend to have a weaker sentiment toward anti-corruption. The regression results confirmed this, as peer influence is significantly associated with anti-corruption attitudes. Individuals who know someone who committed corruption are more likely to have a weaker anti-corruption attitude. The relationship is robust across types of corruption. 
This finding is actually supported by many studies. For example, Dong et al. (2012) and Goel and Nelson (2007) found that the demonstration effect can be important in shaping someone's attitude toward corruption.

\section{Concluding remarks}

This paper tries to revisit the determinants of anti-corruption norms among individuals using the case of Indonesia, with particular attention on the role of income and education. It is motivated by the tendency in literature, particularly in cross-country studies, to identify income as a very strong determinant of corruption level; however, past studies have often failed to recognize that education can also be an important determinant at any given income level. The failure to include education may lead to bias or overestimation of the magnitude of the effect of income.

We estimated an ordered-probit regression model (due to the nature of dependent variables) utilizing a large dataset of 9,020 individuals to represent the Indonesian adult population. The survey elicited the perception of respondents on various kinds of corruption, ranging from bribery to money politics. We included income, education, and various other sociodemographic characteristics as control variables.

We found that income is strongly associated with anti-corruption attitude, where higher income is correlated with a stronger anti-corruption sentiment. However, we found that the effect of income is either weakened or eliminated when we introduced education in the regression. We also found that the effect of education exhibits a nonlinear pattern, which implies that investing in education will have increasing returns in the form of anti-corruption attitude.

The finding that emphasizes the importance of education in shaping corruption norms within society supports the view that increasing access to education is our strongest ally in the anti-corruption campaign, especially in developing countries where the education level is still low. As the finding suggests, a push toward the highest possible level of education can generate higher returns in terms of anti-corruption attitudes within society. In the short term, public education through various media should also be strengthened.

This study, however, has several drawbacks that can be improved in further or extended studies. The analysis in this paper relies solely on an individual's perception. The model identifies the predictors of an individual's perception of corruption, not the predictors of actual corruption. This can suffer from the Hawthorne effect (or sometimes referred to as the observer effect), which refers to a type of activity in which individuals improve an aspect of their behavior in response to their awareness of being observed (McCarney et al., 2007; Bertrand \& Mullainathan, 2001). Bertrand and Mullainathan (2001) saw this from the perspective of a measurement error problem. A measurement error in the subjectively measured variable will produce attenuation bias when the variables enter as a regressor. However, when it comes to the dependent variable as in this study, the 
problem is less serious under certain conditions (i.e., the independent variables are not correlated with the noise); the measurement of attitudes no longer causes bias (Bertrand and Mullainathan, 2001: 70). It would be beneficial for further studies to focus on the extent to which this kind of problem affecting the results of the studies on the cause of corruption measured through perception or opinion.

\section{References}

[1] Alatas, V., Cameron, L., Chaudhuri, A., Erkal, N., \& Gangadharan, L. (2006). Gender and corruption: insights from an experimental analysis. Research Paper 974. Department of Economics, The University of Melbourne. https:/ / minerva-access.unimelb.edu.au/bitstream/handle/11343/34441/ 66972_00002509_01_974.pdf?sequence=1\&isAllowed=y.

[2] Alfonso, H. M. D. (2013). Corruption and Education. A Work Project, presented as part of the requirements for the Award of a Masters Degree in Economics from the NOVA - School of Business and Economics.

[3] Bardhan, P. (1997). Corruption and development: a review of issues. Journal of Economic Literature, 35(3), 1320-1346.

[4] BPS. (2014, January 2). Indeks Perilaku Anti Korupsi (IPAK) Indonesia 2013 sebesar 3,63 dari skala 0 sampai 5. Berita Resmi Statistik No. 07/01/Th. XVII. Badan Pusat Statistik. https:/ /www.bps.go.id/pressrelease/2014/01/02/257/indeks-perilakuanti-korupsi-ipak-indonesia-2013-sebesar-3-63-dari-skala-0-sampai-5-.html.

[5] Chatterjee, I., \& Ray, R. (2012). Does the evidence on corruption depend on how it is measured? Results from a cross-country study on microdata sets. Applied Economics, 44(25), 3215-3227. doi: https://doi.org/10.1080/00036846.2011.570724.

[6] Cressey, D. R. (1950). The criminal violation of financial trust. American Sociological Review, 15(6), 738-743. doi: 10.2307/2086606.

[7] Cressey, D. R. (1953). Other people's money: A study in the social psychology of embezzlement. New York: Free Press.

[8] Dollar, D., Fisman, R., \& Gatti, R. (2001). Are women really the "fairer" sex? Corruption and women in government. Journal of Economic Behavior \& Organization, 46(4), 423-429. doi: https://doi.org/10.1016/S0167-2681(01)00169-X.

[9] Dong, B., Dulleck, U., \& Torgler, B. (2012). Conditional corruption. Journal of Economic Psychology, 33(3), 609-627. doi: https://doi.org/10.1016/j.joep.2011.12.001.

[10] Esarey, J., \& Chirillo, G. (2013). "Fairer sex" or purity myth? Corruption, gender, and institutional context. Politics E Gender, 9(4), 361-389. doi: https:/ /doi.org/10.1017/S1743923X13000378.

[11] Fisman, R., \& Miguel, E. (2006). Cultures of corruption: evidence from diplomatic parking tickets. NBER Working Paper Series 12312. National Bureau of Economic Research. https://www.nber.org/papers/w12312.

[12] Francken, N., Minten, B., \& Swinnen, J. F. (2005). Listen to the Radio! Media and Corruption: Evidence from Madagascar. PRG Working Papers 31872. Katholieke Universiteit Leuven, LICOS - Centre for Institutions and Economic Performance. https://ideas.repec.org/p/ags/kuliwp/31872.html.

[13] Gatti, R., Paternostro, S., \& Rigolini, J. (2003). Individual attitudes toward corruption: do social effects matter?. The World Bank. https://elibrary.worldbank.org/doi/abs/10. 1596/1813-9450-3122. 
[14] Goel, R. K., \& Nelson, M. A. (2007). Are corrupt acts contagious?: Evidence from the United States. Journal of Policy Modeling, 29(6), 839-850. doi: https:/ / doi.org/10.1016/j.jpolmod.2007.09.002.

[15] Gokcekus, O., \& Knörich, J. (2006). Does quality of openness affect corruption?. Economics Letters, 91(2), 190-196. doi: https://doi.org/10.1016/j.econlet.2005.11.015.

[16] Guerrero, M. A., \& Rodríguez-Oreggia, E. (2008). On the individual decisions to commit corruption: A methodological complement. Journal of Economic Behavior $\mathcal{E}$ Organization, 65(2), 357-372. doi: https://doi.org/10.1016/j.jebo.2005.09.006.

[17] Hauk, E., \& Saez-Marti, M. (2002). On the cultural transmission of corruption. Journal of Economic Theory, 107(2), 311-335. doi: https://doi.org/10.1006/jeth.2001.2956.

[18] Melgar, N., Rossi, M., \& Tom W. Smith. (2010). The perception of corruption. Documentos de Trabajo 05/08. Department of Economics - dECON, Facultad de Ciencias Sociales. Universidad de la República. https://ideas.repec.org/p/ude/wpaper/0508.html.

[19] Montinola, G. R., \& Jackman, R. W. (2002). Sources of corruption: A cross-country study. British Journal of Political Science, 32(1), 147-170. doi: https://doi.org/10.1017/S0007123402000066.

[20] Olken, B. A. (2009). Corruption perceptions vs. corruption reality. Journal of Public Economics, 93(7-8), 950-964. doi: https://doi.org/10.1016/j.jpubeco.2009.03.001.

[21] Ortega, D. L., Florax, R. J., \& Delbecq, B. A. (2010). Primary determinants and the spatial distribution of corruption. Working Paper \# 10-6. Dept. of Agricultural Economics, Purdue University. https:/ /ageconsearch.umn.edu/record/101395/.

[22] Paldam, M. (2002). The cross-country pattern of corruption: economics, culture and the seesaw dynamics. European Journal of Political Economy, 18(2), 215-240. doi: https:/ / doi.org/10.1016/S0176-2680(02)00078-2.

[23] Sandholtz, W., \& Koetzle, W. (2000). Accounting for corruption: Economic structure, democracy, and trade. International Studies Quarterly, 44(1), 31-50. doi: https://doi.org/10.1111/0020-8833.00147.

[24] Swamy, A., Knack, S., Lee, Y., \& Azfar, O. (2001). Gender and corruption. Journal of Development Economics, 64(1), 25-55. doi: https://doi.org/10.1016/S0304-3878(00)001231.

[25] Treisman, D. (2000). The causes of corruption: a cross-national study. Journal of Public Economics, 76(3), 399-457. doi: https:/ / doi.org/10.1016/S0047-2727(99)00092-4.

[26] Treisman, D. (2007). What have we learned about the causes of corruption from ten years of cross-national empirical research?. Annual Review of Political Science, 10, 211-244. doi: https://doi.org/10.1146/annurev.polisci.10.081205.095418.

[27] Truex, R. (2011). Corruption, attitudes, and education: Survey evidence from Nepal. World Development, 39(7), 1133-1142. doi: https://doi.org/10.1016/j.worlddev.2010.11.003. 